\title{
PENGARUH PROFITABILITAS, LEVERAGE, UKURAN PERUSAHAAN, KEPEMILIKAN INSTITUSIONAL DAN KEPEMILIKAN MANAJERIAL TERHADAP MANAJEMEN LABA
}

\author{
Dendi Purnama, SE, M.Si \\ dendipurnama90@gmail.com
}

Universitas Kuningan

\begin{abstract}
This study aims to analyze the effect of profitability, leverage, firm size, institutional ownership and managerial ownership of earnings management. The population in this study are all manufacturing companies listed on the Indonesia Stock Exchange from 2010 to 2015. The sample in this study as many as 47 companies for 6 years.

The result of analysis shows that profitability have a significant positive effect to earnings management, firm size and managerial ownership negatively affect earnings management, while leverage and institutional ownership have no effect to earnings management. While jointly shows that the variable profitability, firm size, leverage, institutional ownership and managerial ownership have a significant effect on earnings management.
\end{abstract}

Keywords: Profitability, Leverage, Company Size, Institutional Ownership, Managerial Ownership and Profit Management,

\section{Pendahuluan}

Laporan tahunan perusahaan pada dasarnya merupakan sumber informasi bagi investor sebagai salah satu dasar pertimbangan dalam pengambilan keputusan di pasar modal (Ojk, 2012). Laporan tahunan memberikan informasi mengenai kondisi keuangan dan informasi non keuangan kepada pemegang saham, kreditur, stakeholders dan calon stakeholders lainnya. Informasi kondisi keuangan merupakan salah satu informasi yang di butuhkan pihak eksternal dalam menilai kinerja suatu perusahaan melalui laporan keuangan perusahaan. Laporan keuangan yang diperoleh pihak eksternal adalah bentuk pertanggung jawaban dari hasil akhir proses akuntansi, untuk menimbang kinerja manajemen perusahaan. Salah satu pengukuran kinerja manajemen perusahaan adalah melalui analisis informasi laba yang ada pada laporan keuangan. Oleh karena itu, informasi laba ini sering menjadi target tindakan oportunis manajemen untuk memaksimumkan kepuasaannya. Hal tersebut dapat merugikan pihak eksternal. Tindakan oportunis tersebut sering dilakukan dengan cara mengatur laba perusahaan, yaitu dengan menaikan maupun menurunkan laba dengan menggunakan kebijakan akuntansi tertentu agar informasi mengenai 
laba perusahaan sesuai dengan keinginan. Adanya perbedaan kepentingan antara manajemen dengan pihak eksternal tersebut mendorong manajemen perusahaan memanipulasi laporan keuangan agar terlihat baik,sehingga kinerja manajemen juga terlihat baik. Tindakan-tindakan yang dilakukan oleh manajemen tersebut dikenal dengan istilah manajemen laba (earnings management). Menurut Sulistyanto (2008) manajemen laba adalah upaya manajer perusahaan untuk mengintervensi atau mempengaruhi informasi dalam laporan keuangan dengan tujuan untuk mengelabui stakeholder yang ingin mengetahui kinerja dan kondisi perusahaan. Selain itu, ada juga beberapa pihak yang dirugikan oleh praktik manajemen laba antara lain calon investor, kreditur, supplier, regulator, dan stakeholder lainnya.

Profitabilitas merupakan kemampuan perusahaan mendapatkan laba melalui semua kemampuan, dan sumber yang ada (Harahap, 2009). Profitabilitas mempunyai informasi yang penting bagi pihak eksternal karena apabila profitabilitas tinggi maka kinerja perusahaan dapat dikatakan baik dan apabila profitabilitas rendah maka kinerja perusahaan dapat dikatakan buruk profitabilitas dapat mempengaruhi manajer untuk melakukan tindakan manajemen laba. Selain itu, terdapat hubungan antara profitabilitas dengan motivasi metode bonus plan hypothesis yang merupakan salah satu faktor dari manajemen laba.

Komponen lain yang dapat dijadikan penilaian kinerja perusahaan oleh pihak ekternal adalah leverage. Rasio leverage merupakan rasio yang mengukur seberaha jauh perusahaan dibiayai oleh kewajiban atau pihak luar dengan kemampuan perusahaan yang digambarkan oleh ekuitas (Harahap, 2009). Leverage menunjukkan proporsi penggunaan utang untuk membuayai investasinya. Semakin besar utang perusahaan maka semakin besar risiko yang dihadapi perusahaan sehingga Akibatnya kondisi tersebut mendorong manajemen perusahaan untuk melakukan praktik income smoothing (Tampubolon,2005).

Ukuran perusahaan adalah suatu perbandingan dimana dapat diklasifikasikan besar dan kecilnya perusahaan dengan beberapacara, antara lain: total aset, $\log$ size, nilai pasar saham (Azlina, 2010). Handayani dan Rachadi (2009) yang menunjukan bahwa ukuran perusahaan mempunyai pengaruh negatif terhadap manajemen laba.

Kepemilikan institusional adalah kepemilikan saham perusahaan yang dimiliki oleh institusi atau lembaga (Tarjo, 2008). Kepemilikan institusional memiliki arti penting dalam memonitor pihak manajemen perushaaan karena kepemilikan institusional dimiliki oleh pihak eksternal sehingga dapat mengawasi pihak internal lebih optimal. Tingkat kepemilikan institusional yang tinggi akan menimbulkan usaha pengawasan yang lebih besar oleh pihak investor institutional sehingga dapat menghalangi perilaku oportunistik manajer.

Secara teoritis, pihak manajemen yang memiliki persentase yang tinggi dalam kepemilikan saham akan bertindak 
layaknya seseorang yang memegang kepentingan dalam perusahaan. Manajer yang memegang saham perusahaan akan ditinjau oleh pihak-pihak yang terkait dalam kontrak seperti pemilihan komite audit yang menciptakan permintaan untuk pelaporan keuangan berkualitas oleh pemegang saham, kreditur, dan pengguna laporan keuangan untuk memastikan efisiensi kontrak yang dibuat dibuat. Dengan demikian, manajemen akan termotivasi untuk mempersiapkan laporan keuangan yang berkualitas. Hal ini akan mencerminkan kondisi kontrak yang lebih baik (Ball et al., 2000). Oleh karena itu, kemungkinan bahwa tingkat kepemilikan manajerial akan berada di arah yang sama untuk menekan pemanfaatan akrual diskresioner (manajemen laba) oleh pihak manajemen.

Berdasarkan uraian di atas dan hasil dari penelitian-penelitian terdahalu yang berbeda-beda sehingga adanya fenomena gap dan research gap, maka penulis tertarik untuk melakukan peneltian yang berjudul "Analisis Pengaruh Profitabilitas, Leverage, Ukuran Perusahaan, Kepemilikan Institusional dan Kepemilikan Manajerial Terhadap Manajemen Laba".

\section{Telaah Literatur Dan} Pengembangan Hipotesis

2.1 Agency Theory (Teori Keagenan) Jensen dan Meckling (1976) menjelaskan hubungan keagenan di dalam teori agensi (agency theory) bahwa perusahaan merupakan kumpulan kontrak (nexus of contract) antara pemilik sumber daya ekonomis (principal) dan manajer (agent) yang mengurus penggunaan dan pengendalian sumber daya tersebut. Dalam konsep teori akuntansi, manajemen sebagai agen seharusnya melakukan tindakan yang selaras dengan kepentingan prinsipal, namun manajemen dapat melakukan tindakan-tindakan yang hanya memaksimalkan kepentingan sendiri.

\subsection{Teori Akuntansi Positif}

Watts dan Zimmerman (1986) yang menjelaskan tentang kebijakan akuntansi dan praktiknya dalam perusahaan serta memprediksi kebijakan apa yang akan dipilih manajer dalam kondisikondisi tertentu dimasa yang akan datang. Penentuan kebijakan akuntansi dan praktik yang tepat merupakan hal yang penting bagi perusahaan dalam hal penyusunan laporan keuangan. Teori ini memprediksi adanya tiga hipotesis yang mendorong manajemen untuk melakukan manajemen laba. Ketiga hipotesis tersebut yaitu: hubungan keagenan antara manajer dengan pemilik (bonus plan hypothesis), hubungan keagenan antara manajer dengan kreditur (debt to equity hypothesis), Hubungan keagenan antara manajer dan pemerintah (political cost hypothesis).

\subsection{Hubungan Profitabilitas dengan Manajemen Laba}

Salah satu tujuan perusahaan beroperasi adalah untuk memperoleh laba. Jika profitabilitas yang didapat perusahaan rendah, maka bonus yang diterima oleh manajemen perusahaan pun ikut rendah. Oleh karena itu umumnya pihak manajemen cenderung akan melakukan tindakan manajemen 
laba agar pihak manajemen perusahaan mendapatkan bonus atau kompensasi. Sehingga apabila profitabilitas tinggi maka investor akan percaya bahwa kinerja perusahaan tersebut baik. Widyastuti (2009) menyatakan semakin besar tingkat profitabilitas maka semakin besar terjadinya manajemen laba. Guna dan Herawati (2010) menyatakan bahwa profitabilitas berpengaruh positif terhadap manajemen laba. Berdasarkan uraian di atas, maka hipotesis yang diajukan sebagai berikut:
H1: Profitabilitas berpengaruh positif terhadap manajemen laba

\subsection{Hubungan Leverage dengan Manajemen Laba}

$\begin{array}{cr}\text { Leverage } & \text { merupakan } \\ \text { perbandingan antara total }\end{array}$
kewajiban dengan total aset perusahaan. Semakin tinggi rasio leverage maka semakin tinggi risiko perusahaan dalam membayar kewajibannya sehingga hal ini akan berdampak pada kepercayaan kreditur. Nilai rasio leverage yang tinggi dianggap mempunyai banyak utang kepada pihak eksternal. Akibatnya kondisi tersebut mendorong manajemen perusahaan untuk melakukan praktik income smoothing (Tampubolon, 2005). Begitu pula dengan penelitian yang dilakukan oleh Widyastuti (2009) menyatakan bahwa leverage yang tinggi mendorong manajemen perusahaan untuk melakukan pengelolaan laba. Penelitian Berdasarkan uraian di atas, maka hipotesis yang diajukan sebagai berikut:

$\mathrm{H} 2$ : Leverage berpengaruh positif terhadap manajemen laba.

\subsection{Hubungan Ukuran Perusahaan} dengan Manajemen Laba

Ukuran perusahaan adalah suatu skala di mana dapat diklasifikasikan besar kecil perusahaan menurut berbagai cara, antara lain total aktiva, $\log$ size, penjualan dan nilai pasar saham (Kusumawardhani, 2012). Semakin besar ukuran perusahaan, maka semakin kecil pengelolaan laba yang dilakukan manajemen, sedangkan semakin kecil ukuran perusahaan, maka semakin besar pengelolaan laba yang dilakukan manajemen (Siregar dan Utama, 2005). Lee \& Choi (2002) menyatakan dimana perusahaanperusahaan kecil lebih cenderung melakukan pengelolaan laba dibandingkan perusahaan besar. Berdasarkan uraian di atas, maka hipotesis yang diajukan sebagai berikut:

H3: Ukuran perusahaan berpengaruh negatif terhadap manajemen laba

\subsection{Hubungan Kepemilikan Institusional dengan Manajemen Laba}

Kepemilikan institusional mempunyai pengaruh yang negatif terhadap praktik manajemen laba, semakin kecil persentase kepemilikan institusional maka semakin besar pula kecenderungan pihak manajer dalam mengambil kebijakan akuntansi tertentu untuk memanipulasi pelaporan laba (Widyastuti, 2009). Penelitian Sumanto dan Kiswanto (2014), Mahariana dan Ramantha (2014) menyatakan bahwa kepemilikan institusional berpengaruh negatif terhadap manajemen laba. Berdasarkan uraian tersebut, dalam 
penelitian ini diajukan hipotesis sebagai berikut:

H4: Kepemilikan institusional berpengaruh negatif terhadap manajemen laba.

\subsection{Hubungan Kepemilikan \\ Manajerial dengan Manajemen Laba}

Penelitian rebelumya
bahwa
kengungkapkan $\begin{array}{r}\text { manajerial } \\ \text { terhadap }\end{array}$
berpengaruh negatif dan bisa
manajemen laba dan
meningkatkan kualitas dari proses
pelaporan keuangan, hal ini
dikarenakan ketika manajer juga
memiliki porsi kepemilikan saham,
maka mereka akan bertindak sama
seperti pemegang saham pihak
eksternal dan memastikan bahwa
laporan keuangan telah disajikan
dengan wajar dan mengungkapkan
kondisi riil perusahaan (Kouki et
al., 2011). Hasil penelitian
Oktovianti dan Agustia (2012),
yang menyatakan bahwa

kepemilikan manajerial ini berpengaruh negatif signifikan terhadap manajemen laba. Berdasarkan uraian tersebut, dalam penelitian ini diajukan hipotesis sebagai berikut:

H5: Kepemilikan manajerial berpengaruh negatif terhadap manajemen laba

\section{Metode Penelitian}

Metode penelitian yang digunakan dalam penelitian ini adalah metode deskriptif dan verifikatif. Populasi penelitian ini adalah seluruh perusahaan yang terdaftar di Bursa Efek Indonesia tahun 2010 sampai dengan tahun 2015. Jumlah perusahaan manufaktur yang secara berturutturut terdaftar di BEI tahun 2010 sampai 2015 adalah sebanyak 140 perusahaan. Berdasarkan hasil dari purposive sampling method yang dilakukan maka diperoleh jumlah sampel sebanyak 47 perusahaan selama 6 tahun.

\section{Operasional Variabel Dependen}

\section{A. Manajemen Laba}

Berikut adalah model perhitungan discretionary accrual model Modified Jones menurut Dechow, Sloan, Sweeney (1995):

TACCit $=$ Nit - CFOit

Dimana:

TACit $=$ Total accrual perusahaan i pada tahun $\mathrm{t}$

Niit = Net income perusahaan i pada tahun $\mathrm{t}$

$\mathrm{CFOit}=$ Arus kas operasi perusahaan i pada tahun $\mathrm{t}$

Untuk mengetahui nilai dari nondiscretionary accrual, maka perlu menghitung koefisien dari

regresi akrual yang diketahui dengan melakukan regresi sebagai berikut:

TACCit/Tait-1 $=\alpha(1 /$ Tait-1) $+\beta 1[(\Delta$ SALit- $\Delta$ RECit $) /$ Tait-1) $+\beta 2($ PPEit $/$ Tait-

1) + eit

Dimana:

TACCit $=$ Total accrual perusahaan i pada tahun $\mathrm{t}$

Tait $-1=$ Total aset perusahaan i pada tahun $\mathrm{t}-1$

$\triangle$ SALit $=$ Perubahan penjualan bersih perusahaan $\mathrm{i}$ antara tahun $\mathrm{t}$ dan tahun $\mathrm{t}-1$

$\triangle$ RECit $=$ Perubahan piutang perusahaan $\mathrm{i}$ antara tahun $\mathrm{t}$ dan tahun $\mathrm{t}-1$

PPEit $=$ Nilai perolehan aktiva tetap pada perusahaan $\mathrm{i}$ pada tahun $\mathrm{t}$ 
Eit $\quad=$ Error term

Persamaan Total accrual

regresi OLS terebut dan diatas diestimasi dengan metode Ordinary Least Square (OLS). Estimasi $\alpha, \beta 1, \beta 2$ diperoleh dari digunakan untuk menghitung Non Discretionary Accrual sebagai berikut:

NDACCit $=\alpha(1 /$ Tait -1$)+\beta 1[(\Delta$ SALit- $\Delta$ RECit/Tait-1 $]+\beta 2($ PPEit $/$ Tait-1 $)+\varepsilon i t \ldots . .(3)$

Setelah melakukan regresi atas model di atas, Discretionary Accrualdapat dihitung dengan persamaan:

DACCit $=($ TACCit $/$ AAit -1$)-$ NDACCit

\section{Operasional \\ Independen}

A. Profitabilitas

Profitabilitas dalam penelitian ini menggunakan Return on Asset (ROA). ROA digunakan untuk mengukur kemampuan manajemen dalam memperoleh keuntungan (laba) secara keseluruhan. Menurut Kasmir (2011) Return on Asset (ROA)

ROA =Laba bersih setelah pajak Total aset

\section{Ukuran perusahaan}

Ukuran perusahaan adalah skala untuk menentukan besar kecilnya perusahaan yang dihitung dengan menggunakan logaritma natural dari total aktiva, sehingga dapat dirumuskan sebagai berikut (Budiasih, 2009). diukur dengan menggunakan rumus:

Firm Size $=$ Ln Total Aset

\section{B. Leverage}

Leverage merupakan rasio yang menunjukan kuantitas hutang atau kewajiban perusahaan terhadap total aset (Solihin, 2009). Menurut Wild dan Subramanyam (2009) rumus debt to equity ratio adalah sebagai berikut:

$$
D E R=\frac{\text { total hutang }}{\text { total ekuitas }}
$$

\section{Kepemilikan Institusional} Kepemilikan institusional merupakan kepemilikan saham perusahaan oleh institusi keuangan seperti perusahaan asuransi, bank, dana pensiun, dan investment banking (Siregar dan Utama, 2005). Rumus kepemilikan institusional sebagai berikut.

Jumlah saham yang dimiliki investor institusional

total modal saham perusahaan yang beredar

\section{E. Kepemilikan Manajerial \\ Kepemilikan manajerial adalah persentase jumlah}

kepemilikan saham yang dimiliki oleh manajemen dari seluruh jumlah saham 
perusahaan yang beredar

(Mahariana dan Ramantha,

2014). Rumus kepemilikan

manajerial sebagai berikut.

Jumlah saham yang dimiliki pihak manajemen

total modal saham perusahaan yang beredar

\section{Pembahasan}

\subsection{Statistik Deskriptif}

Hasil pengukuran statistik deskriptif dalam penelitian ini untuk variabel independen berupa nilai minimum dan maksimum, nilai rata-rata serta deviasi standar dapat dilihat pada tabel berikut ini

\section{Tabel 4.1}

Hasil Statistik Deskriptif

\begin{tabular}{lrrrrr}
\hline & $\mathrm{N}$ & \multicolumn{1}{c}{ Minimum } & Maximum & \multicolumn{1}{c}{ Mean } & Std. Deviation \\
X1 & 282 & $-0,6193$ & 0,4792 & 0,0436 & 0,0868 \\
X2 & 282 & $-10,3407$ & 7,3716 & 1,2417 & 1,5869 \\
X3 & 282 & 25,0092 & 31,9712 & 28,0502 & 1,7810 \\
X4 & 282 & 0,0010 & 0,9899 & 0,5878 & 0,3063 \\
X5 & 282 & 0,0000 & 0,9990 & 0,1670 & 0,2802 \\
Y & 282 & $-1,6962$ & 1,9921 & 0,0976 & 0,6496 \\
Valid N (listwise) & 282 \\
\multicolumn{4}{c}{ Sumber: data diolah dari SPSS } \\
\multicolumn{5}{l}{}
\end{tabular}

Berdasarkan Tabel 4.1 di atas, diketahui bahwa jumlah sampel yang diobservasi dalam penelitian ini adalah sebanyak 282 laporan tahunan. Nilai minimum dari profitabilitas adalah $-0,6193$, nilai maksimumnya 0,4792 , nilai rataratanya adalah $-0,0436$ dan standar deviasinya adalah 0,0868. Nilai minimum dari leverage adalah 10,3407, nilai maksimumnya adalah 7,3716 , nilai rata-ratanya adalah 1,2417 dan standar deviasinya adalah 1,5869.Nilai minimum dari ukuran perusahaan adalah 25,0092, nilai maksimumnya adalah 31,9712, nilai rata-ratanya adalah 28,0502dan standar deviasinya adalah 1,7810.Nilai minimum dari kepemilikan institusional adalah 0,0010 , nilai maksimumnya adalah 0,9899 nilai rata-ratanya adalah 0,5878dan standar deviasinya adalah 0,3063. Nilai minimum dari kepemilikan manajerial adalah 0,0000 , nilai maksimumnya adalah 0,9990 nilai rata-ratanya adalah 0,1670dan standar deviasinya adalah 0,2802. Nilai minimum dari manajemen laba adalah -1,6962, nilai maksimumnya adalah 1,9921 nilai rata-ratanya adalah 0,0976 dan standar deviasinya adalah 0,6496. 


\subsection{Pembahasan}

Tabel 4.2

Hasil Uji t

\begin{tabular}{lrrc}
\hline \multicolumn{1}{c}{ Model } & Koefisien & \multicolumn{1}{l}{ T } & \multicolumn{1}{l}{ Sig. } \\
\hline (Constant) & 1,718 & 2,761 & 0,006 \\
Profitabilitas & 0,688 & 2,118 & 0,016 \\
Leverage & 0,006 & 0,208 & 0,835 \\
Ukuran Perusahaan & $-0,063$ & $-2,829$ & 0,005 \\
Kepemilikan Institusional & 0,113 & 0,687 & 0,493 \\
Kepemilikan Manajerial & $-0,320$ & $-1,776$ & 0,037 \\
\hline
\end{tabular}

Sumber: data diolah dari SPSS

Berdasarkan tabel di atas, maka dapat disusun model persamaan

regresi linier berganda sebagai $Y=1,718+0,688 X_{1}+0,006 X_{2}-0,063 X_{3}+0,113 X_{4}-0,320 X_{5}$

\subsubsection{Pengaruh Profitabilitas terhadap Manajemen Laba}

Pengujian hipotesis pertama menyatakan bahwa profitabilitas berpengaruh positif terhadap manajemen laba. Hasil penelitian ini menunjukkan bahwa nilai $\mathrm{t}$ hitung sebesar 2,118 dengan tingkat signifikan sebesar 0,016. Hal ini mengindikasikan bahwa tindakan manajemen perusahaan cenderung melakukan manajemen laba dengan cara income minimization (minimisasi laba) maupun income maximization (maksimisasi laba). Perilaku manajemen perusahaan dalam manajemen laba dengan cara income minimization (minimisasi laba) bertujuan untuk keperluan pertimbangan pajak yaitu meminimkan kewajiban pajak perusahaan, sedangkan cara income maximization (maksimisasi laba) yang dimaksudkan untuk memaksimumkan bonus manajer, menciptakan kinerja perusahaan yang baik sehingga dapat meningkatkan nilai perusahaan (pertimbangan pasar modal) yang bertujuan untuk mendapatkan kepercayaan dari investor agar mau berinventasi diperusahaan tersebut, menunda pelanggaran perjanjian utang serta manajer dapat memperoleh kendali atas perusahaan.

Hasil penelitian ini sesuai dengan agency theory dimana manajemen perusahaan sebagai agen melakukan tindakan yang hanya mementingkan kepentingan sendiri karena telah melakukan manipulasi laporan keuangan sehingga merugikan pihak investor. Selain itu, penelitian ini mendukung teori akuntansi positif yang menerangkan adanya motivasi bagi manajemen perusahaan untuk melakukan tindakan manajemen laba. Dengan cara mengatur laba yang dilaporkannya dengan tujuan dapat memaksimalkan jumlah bonus yang akan diterimanya.

Hasil penelitian ini sesuai dengan penelitian yang dilakukan Guna dan Herawaty (2010), Amerta (2013), Bok et al. (2011), Hamza dan Lakhal (2010), 
Widyastuti (2009) serta Shimin et al. (2009) yang mengemukakan bahwa profitabilitas berpengaruh positif signifikan terhadap manajemen laba.

\subsubsection{Pengaruh Leverage terhadap Manajemen Laba}

Pengujian hipotesis ketiga menunjukkan bahwa hipotesis ketiga ditolak. Hasil itu terbukti dari nilai t yang dihasilkan sebesar 0,208 dengan tingkat signifikan 0,835 yang berarti lebih besar dari 0,05. Dengan demikian, dapat diambil kesimpulan bahwa dalam penelitian ini leverage tidak berpengaruh terhadap manajemen laba. Hal ini mengindikasikan bahwa bahwa semakin tinggi atau rendahnya leverage tidak akan mempengaruhi manajemen laba. Hal ini disebabkan karena perusahaan manufaktur yang dijadikan sampel tidak tergantung pada utang dalam membiayai aset perusahaan, sehingga tidak mempengaruhi terhadap keputusan manajemen perusahaan dalam pengaturan jumlah laba yang akan dilaporkan apabila terjadi perubahan pada tingkat utang. Selain itu, hasil tersebut menunjukkan bahwa informasi mengenai leverage perusahan yang termuat dalam laporan tahunan memberikan informasi yang kurang bermakna bagi investor maupun kreditur, padahal leverage dapat memicu praktik manajemen laba dikarenakan kepentingan perusahaan untuk memperoleh modal dari kreditur dan perhatian investor.

Hasil penelitian ini tidak sesuai dengan teori keagenan yang dikemukakan Jensen dan Meckling (1976) bahwa terdapat hubungan keagenan antara manajer dan kreditur (debt to equity hypothesis) dimana perusahaan yang mempunyai rasio leverage yang tinggi maka manajer perusahaan tersebut cenderung menggunakan metode akuntansi yang akan meningkatkan laba agar kinerja perusahaan terlihat baik dengan harapan kreditur dapat mempercayai kinerja perusahaan tersebut. Sehingga informasi tersebut dapat meyakinkan kreditur yang beranggapan bahwa debitur dapat membayarkan hutangnya kepada principal (kreditur).

Hasil penelitian ini sejalan dengan penelitian yang dilakukan oleh Mohamad et al. (2015), Rice (2013) serta Jao dan Gagaring (2011) yang menyatakan bahwa leverage tidak berpengaruh terhadap manajemen laba

\subsubsection{Pengaruh Ukuran Perusahaan Manajemen Laba}

Pengujian hipotesis ketiga menyatakan bahwa ukuran perusahaan berpengaruh negatif terhadap manajemen laba. Hasil penelitian ini menunjukkan bahwa nilai $t$ hitung sebesar $-2,829$ dengan tingkat signifikan sebesar 0,005. Hal ini mengindikasikan bahwa semakin besar ukuran perusahaan, maka semakin kecil manipulasi laba yang dilakukan manajemen perusahaan. Karena semakin besar perusahaan maka semakin ketat pengawasan terhadap pihak internal perusahaan. Dengan demikian, dapat meminimalisir tindakan manajemen perusahaan dalam melakukan kecurangan mengenai informasi laba. Informasi yang 
dipublikasikan kepada pihak eksternal akan semakin transparan dan lengkap sehingga perusahaan yang berukuran besar lebih diminati oleh investor dan broker.

Hasil penelitian ini sesuai dengan penelitian yang dilakukan oleh Rice (2013), Siregar dan Utama (2005), serta Lee and Choi (2002), yang menyatakan ukuran perusahaanberpengaruh negatif signifikan terhadap manajemen laba.

\subsubsection{Pengaruh Institusional Manajemen Laba \\ Kepemilikan terhadap}

Pengujian hipotesis keempat menunjukkan bahwa hipotesis keempat ditolak. Hasil itu terbukti dari nilai t yang dihasilkan sebesar 0,687 dengan tingkat signifikan 0,493 yang berarti lebih besar dari 0,05. Dengan demikian, dapat diambil kesimpulan bahwa dalam penelitian ini kepemilikan institusional tidak berpengaruh terhadap manajemen laba. Hal ini mengindikasikan bahwa semakin tinggi atau rendahnya porsi kepemiliian saham yang dimiliki pihak institusional tidak begitu berarti sebagai alat untuk mengawasi tindakan pihak internal perusahaan dalam melakukan kecurangan mengenai informasi laba di dalam laporan keuangan. Padahal kepemilikan institusional memiliki arti penting dalam memonitor manajemen karena dengan adanya kepemilikan oleh institusional akan mendorong peningkatan pengawasan yang lebih optimal. Selain itu, dari sampel data penelitian diketahui ada beberapa perusahaan memiliki proporsi kepemilikan saham yang tidak stabil.

Hasil penelitian ini berlawanan dengan teori keagenan, dimana kepemilikan institusional seharusnya memiliki peranan yang sangat penting dalam meminimalisasi konflik keagenan yang terjadi antara pihak manajer dan pemegang saham. Keberadaan investor institusional dianggap mampu menjadi mekanisme monitoring yang efektif dalam setiap keputusan yang diambil oleh manajer. Akan tetapi, hal ini tidak begitu berlaku pada penelitian ini.

Hasil penelitian inisesuai dengan penelitian yang dilakukan oleh Mahariana dan Ramantha (2014), serta Astuti (2006) yang menyatakan bahwa kepemilikan institusional tidak berpengaruh terhadap manajemen laba

\subsubsection{Pengaruh \\ Manajerial \\ Manajemen Laba}

Kepemilikan terhadap

Pengujian hipotesis ketiga menyatakan bahwa ukuran perusahaan berpengaruh negatif terhadap manajemen laba. Hasil penelitian ini menunjukkan bahwa nilai $\mathrm{t}$ hitung sebesar $-2,829$ dengan tingkat signifikan sebesar 0,005 . Berdasarkan penjelasan di atas menunjukkan bahwa semakin besar kepemilikan manajerial maka tindakan manajemen laba yang dilakukan oleh manajemen perusahaan semakin menurun. Sehingga pihak manajemen akan efisien memilih metode akuntansi yang memberikan nilai tambah bagi perusahaan. Manajer yang memegang saham perusahaan akan termotivasi untuk mempersiapkan laporan keuangan 
yang berkualitas. Dengan demikian, pihak manajer akan mengawasi pihak internal perusahaan sehingga akan mengurangi tindakan manajemen laba.

Hasil penelitian ini sesuai dengan teori keagenan, dimana teori keagenan menjelaskan bahwa manajer sebagai pelaksana (agen) dan investor sebagai pemilik (prinsipal) yang mempunyai tujuan berbeda terhadap informasi laba. Maka dengan semakin besar kepemilikan manajerial semakin kuat pengendalian internal perusahaan sehingga akan mengawasi pihak internal melakukan manajemen laba.

Hasil penelitian ini sesuai dengan penelitian yang dilakukan oleh Mahariana dan Ramantha (2014) serta Widyastuti (2009) yang menyatakan kepemilikan manajerial berpengaruh negatif signifikan terhadap manajemen laba.

\section{Penutup}

\subsection{Kesimpulan}

dan pembahasan, maka kesimpulan yang dapat diambil dari penelitian ini sebagai berikut:

1) Profitabilitas berpengaruh positif terhadap manajemen laba.

2) Leverage tidak berpengaruh terhadap manajemen laba.

3) Ukuran perusahaan berpengaruh negatif terhadap manajemen laba.

4) Kepemilikan Institusional tidak berpengaruh terhadap manajemen laba.
5) Kepemilikan Manajerial berpengaruh negatif terhadap manajemen laba.

\subsection{Implikasi}

Dari penelitian yang telah dilakukan oleh penulis, maka implikasi dari penelitian ini adalah dapat memperkaya materi pembelajaran dan bisa dijadikan referensi untuk riset yang akan datang terkait dengan faktorfaktor yang mempengaruhi manajemen laba, bagi pihak internal perusahaan, penelitian ini diharapkan dapat dijadikan sebagai bahan pertimbangan tentang pentingnya transparansi dan akuntabilitas dalam penyusunan laporan keuangan, dan penelitian ini diharapkan dapat memberikan informasi mengenai kinerja dari suatu perusahaan dan membantu investor dalam hal pengambilan keputusan yang tepat untuk penanaman investasi.

\subsection{Keterbatasan}

Penelitian ini memiliki keterbatasan meskipun peneliti telah berusaha mengembangkan penelitian sedemikian rupa. Berikut adalah beberapa keterbatasan dalam penelitian ini yang masih perlu direvisi pada penelitian selanjutnya, yaitu:Masih banyak data yang kurang lengkap sehingga memperkecil sampel yang digunakan. penelitian ini hanya menggunakan perusahaan manufaktur sebagai obyek penelitian sehingga obyek penelitian belum mencakup 
keseluruhan jenis perusahaan yang ada, model regresi linear dalam penelitian ini menghasilkan nilai adjusted $R$ square yang masih relatif rendah yaitu sebesar 0,251 . Hal ini menunjukkan kemampuan variabel independen dalam menjelaskan variasi variabel dependen hanya $25,1 \%$ sisanya $74,9 \%$ dipengaruhi oleh variabel lain yang tidak diteliti., hasil penelitian ternyata tidak mendukung teori dan hipotesis tentang arah dan pengaruh dari variabel leverage dan kepemilikan institusional dalam mempengaruhi manajemen laba perusahaan manufaktur.

\subsection{Saran}

Saran yang dapat diberikan peneliti untuk riset yang akan datang yaitu: penelitian berikutnya sebaiknya memperluas sampel penelitian dan pengujian pengamatan yang lebih lama sehingga dapat memberikan hasil yang lebih baik, model regresi linear dalam penelitian ini menghasikan nilai Adjusted $\mathrm{R}$ square yang masih relatif rendah yaitu $25,1 \%$. Oleh karena itu, terdapat kemungkinan penelitian selanjutnya untuk mencari variabel independen lain yang mempengaruhi manajemen laba, dan penelitian selanjutnya hendaknya mengkaji ulang hasil penelitian pada periode penelitian dan menggunakan proxy yang berbeda khususnya terkait dengan variabel leverage, diharapkan hal tersebut dapat memberikan hasil pengujian yang lebih baik.

\section{DAFTAR PUSTAKA}

Astuti, D. S. Puji. 2004. Analisis Faktor-Faktor Yang Mempengaruhi Motivasi Manajemen Laba Di Seputar Right Issue. Jurnal Akuntansi. Universitas Slamet Riyadi.

Amertha, Indra S. P. 2013. Pengaruh Return On Asset pada Praktik Manajemen Laba dengan Moderasi Corporate Governance. Jurnal Akuntansi Universitas Udayana 4.2 (2013).

Azlina, Nur. 2010. Analisis Faktor yang Mempengaruhi Manajemen Laba. Pekbis Jurnal. Vol.2, No.3, November 2010: 355-363.

Ball, R., Robin, A. dan Wu, J. S. 2000. Accounting Standards, the Institutional Environment and Issue Incentives: Effect on Timely Loss Recognition in China. Asia Pacific Journal ofAccounting and Economics. Vol. 7, Pages 71-96.

Bok, Baik., David B. Farber, and Sam. (Sunghan) Lee. 2011. CEO Ability and Management Earnings Forecasts. Contemporary Accounting Research.28(5): 16451668.

Budiasih, Igan. 2009. Faktor-Faktor yang Mempengaruhi Praktik Perataan Laba. Jurnal Akuntansi Bisnis. Vol 4. No. 1. Januari. Hal 44-50.

Dechow, P.M., Sloan, R. G. \& Sweeney, A. P. 1995. Detecting Earnings Management. Accounting and Business Reseach, Vol. 70, No. 2. 193225. 
Guna, W.I dan Herawaty, A. (2010). "Pengaruh Mekanisme Good Corporate Governance, Independensi Auditor, Kualitas Audit dan Faktor Lainnya Terhadap Manajemen Laba". Jurnal Bisnis Dan Akuntansi. 12(1): 53-68.

Hamza, Taher dan Faten Lakhal. 2010. The Determinants of Earnings Management by The Acquirer: The Case of French Corporate Takeovers. http:univorleans.fr/log/Doc-Rech/TextesPDF/2010-3.pdf. 1-25.

Handayani, Sri dan Rachadi, Agustono. D. 2009. Pengaruh Ukuran Perusahaan terhadap Manajemen Laba. Jurnal Bisnis dan Akuntansi. Vol. 11, No. 1, April 2009.

Harahap, S Sofyan. 2015. Analisis Kritis Laporan Keuangan. Cetakan Kedua belas, edisi.1. Jakarta: Raja Grafindo Persada.

Jao, Robert dan Pagalung, Gagaring. 2011. Corporate Governance, Ukuran Perushaan, dan Leverage terhadap Manajemen Laba Perusahaan Manufaktur Indonesia. Jurnal Akuntansi dan Auditing. Vol. 8, No. 1.

Jensen, Michael C., dan W. H. Meckling. 1976. "Theory of the Firm: Managerial Behavior, Agency Costs, and Ownership Structure." Journal of Financial Economics. Vol. 3, No. 4. pp. 305-360.
Kasmir. 2011. Manajemen Perbankan. Edisi Revisi 2008. PT. Raja Grafindo Persada. Jakarta.

Kouki, M., Abderrazek, E., Hanen, A., and Slim, S. (2011). Does Corporate Governance Constrain Earnings Management? Evidence from U.S. Firms. European Journal of Economics, Finance and Administrative Sciences, 35, 58-71.

$\begin{array}{lrr}\text { Kusumawardhani, } & \text { Indra. } & 2012 . \\ \text { Pengaruh } & & \text { Corporate } \\ \text { Governance, } & & \text { Struktur } \\ \text { Kepemilikan dan } & \text { Ukuran } \\ \text { Perusahaan } & & \text { Terhadap } \\ \text { Manajemen Laba. } & & \end{array}$
1

Lee, B.B. and B. Choi. 2002. Company Size, Auditor Type, and Earnings Management. Journal of Forensic Accounting Vol. III, hlm. 27-50.

Mahariana, I.D.G. dan I.W. Ramantha. 2014. Pengaruh Kepemilikan Manajerial dan Kepemilikan Institusional Pada Manajemen Laba Perusahaan Manufaktur Di Bursa Efek Indonesia. Jurnal Akuntansi Universitas Udayana. Vol. 7, No 2.

Mohamad, Vanli, Zulkifli Bokiu dan Nilawati Yusuf. 2015. Pengaruh Return On Asset (ROA) dan Leverage terhadap Praktik Manajemen Laba Pada Perusahaan Manufaktur Yang Terdaftar Di Bursa Efek Indonesia. Jurnal Akuntansi. Universitas Negeri Gorontalo.

Otoritas Jasa Keuangan. 2012. "Kewajiban Penyampaian Laporan Tahunan Bagi Emiten 
Atau Perusahaan Publik". http://ojk.go.id

Oktovianti, T. and Agustia, D. (2012). Influence of the Internal Corporate Governance and Leverage Ratio to the Earnings Management", Journal of Basic and Applied, 2(7), 7192-7199.

Rice. 2013. Pengaruh Leverage, Kepemilikan Institusional, Ukuran dan Nilai Perusahaan terhadap Tindakan Manajemen Laba. Jurnal Wira Ekonomi Mikroskil. Vol 3, No. 1, 2013.

Shimin, Chen., Yuetang Wang, Ziye Zhao. 2009. Regulatory Incentives for Earnings Management Through Asset Impairment Reversals in China. Journal of Accounting, Auditing, and Finance. 24(4): 589-620.

Siregar, S. Veronica dan S. Utama. 2005. Pengaruh Struktur Kepemilikan, Ukuran

Perusahaan, Praktik Corporate Governance terhadap Pengelolaan Laba (Earning Management). Jurnal Simposium Nasional Akuntansi 8. Solo.

Solihin, Ismail. 2009. Pengantar Manajemen. Jakarta. Erlangga.
Sulistyanto, Sri. 2008. Manajemen Laba, Teori dan Model Empiris. Jakarta: PT. Grasindo.

Sumanto, B., Asrori dan Kiswanto. 2014. Pengaruh Kepemilikan Institusional dan Ukuran Dewan Komisari Terhadap Manajemen Laba. Accounting Analysis Journal Unnes. Vol 3(1).

Tampubolon, Manahan. 2005. Manajemen Keuangan. Edisi Pertama. Jakarta: Ghalia Indonesia.

Tarjo. 2008. Pengaruh Konsentrasi Kepemilikan Institusional dan Leverage terhadap Manajemen Laba, Nilai Pemegang Saham serta Cost of Equity Capital. Simposium Nasional Akuntansi 11. Pontianak.

Watts, R. L. dan J. L. Zimmerman. 1986. Positive Accounting Theory. USA: Prentice-Hall Inc.

Widyastuti, Tri. (2009). Pengaruh Struktur Kepemilikan dan Kinerja Keuangan Terhadap Manajemen Laba: Studi pada Perusahaan Manufaktur di BEI. JurnalMaksi, Vol.9 (1), 30-41.

Wild, John J. dan K.R Subramanyam. 2009. Financial Statement Analysis. $10^{\text {th }} e d$, The USA: McGraw-Hill Companies, Inc. 